\title{
PENGEMBANGAN ALAT UKUR KESEJAHTERAAN PSIKOLOGIS REMAJA USIA 12-15 TAHUN
}

\author{
Fitri Ariyanti Abidin', Rismijati E. Koesma², Poeti Joefiani ${ }^{3}$, Juke R. Siregar ${ }^{4}$ \\ ${ }^{1,2,3,4}$ Fakultas Psikologi Universitas Padjadjaran \\ Jalan Raya Jl. Raya Bandung-Sumedang KM. 21 Jatinangor - Sumedang \\ E-mail: fitri.ariyanti.abidin@unpad.ac.id
}

\begin{abstract}
ABSTRAK
Remaja yang sejahtera secara psikologis akan tumbuh menjadi individu dewasa yang berfungsi secara optimal. Penelitian kesejahteraan psikologis remaja di Indonesia saat ini pada umumnya masih menggunakan alat ukur yang dikonseptualisasi dari subjek dewasa yang berada pada budaya Barat, yang berpotensi menjadi bias. Penelitian ini bertujuan untuk mengembangkan alat ukur kesejahteraan psikologis remaja berdasarkan konseptualisasi dari subjek remaja di Indonesia. Menggunakan rancangan exploratory sequential mixed methods, penelitian ini dilakukan melalui dua tahap; yaitu tahap penelitian kualitatif diikuti dengan tahap penelitian kuantitatif. Tahap penelitian kualitatif ditujukan untuk mengkonseptualisasi kesejahteraan psikologis remaja sebagai tahap pertama dari pengembangan alat ukur kesejahteraan psikologis remaja, dengan menggunakan teknik wawancara dan focused group discussion. Hasil penelitian kualitatif menunjukkan bahwa konsep kesejahteran psikologis remaja usia 12-15 tahun terdiri dari 10 dimensi: afek positif, afek negatif, kepercayaan diri, hubungan positif, orientasi masa depan, pengembangan diri, pengelolaan emosi negatif, tanggung jawab, kemampuan menyelesaikan masalah dan harmoni. Pada tahap kuantitatif, disusun alat ukur berdasarkan kesepuluh dimensi tersebut. Alat ukur diujicobakan sebanyak dua kali, pada 494 dan 297 remaja usia 12-15 tahun. Alat ukur terdiri dari 38 item yang mengukur kesepuluh dimensi, memiliki reliabilitas $(\alpha=0,873)$ dan validitas konstruk $(\mathrm{RMSEA}=0,075 ; \mathrm{GFI}=0,91 ; \mathrm{CFI}=0,93 ; \mathrm{NNFI}=0,91 ; \mathrm{IFI}=0,93)$ yang baik.
\end{abstract}

Kata kunci: kesejahteraan psikologis; remaja; pengembangan alat ukur; mixed methods

\section{DEVELOPMENT OF PSYCHOLOGICAL WELL-BEING MEASUREMENT FOR ADOLESCENT AGE 12-15 YEARS}

\begin{abstract}
Psychologically well-being adolescents will develop into fully functioning adults. Research on adolescents' psychological well-being in Indonesia generally still use measurement conceptualized in the western and adult population context. This potentially brings bias to the result. This study aims to develop psychological well-being measurements based on conceptualization from the adolescent sample in the Indonesia. Using exploratory sequential mixed methods, the study was conducted in two phases: a qualitative study followed by a quantitative study. The qualitative study was aimed at conceptualized adolescent psychological well-being in the Indonesian context as a first step to develop the adolescent psychological well-being measurement, using individual interviews and focused group discussion. The qualitative result showed that psychological well-being on adolescents aged 12-15 years consists of ten dimensions, namely, positive affect, negative affect, self-confidence, positive relationship, future orientation, selfgrowth, negative-emotion management, responsibility, problem-solving skill, and harmony. In the quantitative study, a measure consisting of 109 items spread near evenly among the ten dimensions was developed. Two times tryout was conducted among 494 and 297 adolescents aged 12-15 years. The final38 items yield a high reliability $(\alpha=0,873)$ and supported by sufficient validity evidences (RMSEA =0,075; $G F I=0,91 ; C F I=0,93 ; N N F I=0,91 ; I F I=0,93)$.
\end{abstract}

Keywords: psychological well-being; adolescent; measurement development; mixed methods 


\section{PENDAHULUAN}

Penelitian mengenai remaja, bergerak dari deficit approach yang tujuannya untuk mengurangi kondisi negatif yang dialami remaja ke arah positive youth development approach, yang memandang remaja sebagai individu yang penuh dengan potensi, dan memfokuskan perhatian pada kekuatan remaja. Konsep yang banyak diteliti menggunakan positive youth development approach adalah wellbeing/kesejahteraan psikologis (Viejo, Mercedes, \& Ortega-ruiz, 2018). Kesejahteraan psikologis (KP) adalah suatu terminologi umum yang digunakan untuk menggambarkan kondisi psikologis yang "baik" (well-being). Lawannya adalah kondisi psikologis yang "buruk" (ill-being) (Ryff et al., 2006) (Catatan: istilah "kesejahteraan psikologis" akan ditulis beserta singkatannya KP jika yang dimaksudkan adalah "well-being". Sedangkan jika yang dimaksudkan adalah psychological well-being sebagai pendekatan eudaimonia, maka penulisan "kesejahteraan psikologis tidak akan disertai singkatan KP). Kesejahteraan psikologis (KP) secara empiris telah terbukti berdampak pada perkembangan positif remaja. Sejumlah penelitian menemukan kaitan antara kesejahteraan psikologis (KP) dengan perilaku positif remaja, baik dalam kondisinya saat ini sebagai remaja, maupun setelah ia dewasa. Remaja yang sejahtera secara psikologis mampu menumbuhkan emosi positif yang ada dalam dirinya; merasakan kepuasan hidup dan kebahagiaan dengan melakukan kegiatan yang positif, berkurang dalam rasa depresi dan perilaku negatifnya (Akhtar, 2009), sehat secara mental dan fisik, terhindar dari penyimpangan penggunaan internet dan narkoba (Saha, Huebner, Hills, Malone, \& Valois, 2014), lebih berprestasi dalam bidang akademik, lebih memiliki kompetensi intrapersonal dan interpersonal, serta memiliki coping yang lebih baik saat mengalami masalah dalam kehidupan (Shek \& Lin, 2014). Remaja yang sejahtera secara psikologis saat ini (well-being) akan menjadi individu dewasa yang sejahtera secara psikologis di masa dewasanya (wellbecoming) (Ben-Arieh, Casas, Frones, \& Korbin, 2014).

Karena kualitas perkembangan remaja akan berdampak pada kualitas psikologisnya pada saat ia dewasa (Proctor, Linley, \& Maltby, 2009), maka kajian mengenai kesejahteraan pada remaja menjadi penting. Dalam konteks Indonesia, pada tahun 2035 Indonesia secara kuantitas akan mengalami bonus demografi, yaitu suatu kondisi dimana proporsi penduduk yang produktif lebih banyak dibandingkan dengan yang tidak produktif (Heryanah, 2015). Pada tahun tersebut, individuindividu yang saat ini berada pada tahap remaja, akan masuk menjadi kelompok usia produktif.
Secara ekonomi, bonus demografi hanya dapat dimanfaatkan jika kelompok produktif ini benarbenar berfungsi optimal sebagai individu. Dari tinjauan ekonomi kependudukan, penduduk merupakan aset utama kemajuan bangsa, dengan catatan penduduk tersebut merupakan sumber daya yang berkualitas. Dalam perspektif psikologi, sumber daya yang berkualitas bisa dimaknakan sebagai individu yang memiliki kesejahteraan psikologi yang tinggi. Dengan demikian, kajian mengenai kesejahteraan psikologis remaja merupakan sebuah kebutuhan sosio-psikologis (socio-psychological necessity)(Khan, Taghdisi, \& Nourijelyani, 2015).

Terkait dengan konsep kesejahteraan psikologis, hasil kajian literatur menunjukkan bahwa konsep kesejahteraan psikologis diawali dari filosofi makna "good life", yang menghasilkan dua pandangan yaitu hedonic dan eudaimonic. Dalam tataran ilmu pengetahuan, filosofi hedonic mendasari teori subjective well-being (kesejahteraan subjektif), sedangkan filosofi eudaimonic mendasari teori psychological wellbeing (kesejahteraan psikologis) (Ryan \& Deci, 2001). Tokoh utama yang mengembangkan teori kesejahteraan subjektif adalah Ed Diener, sedangkan tokoh utama yang mengembangkan teori kesejahteraan psikologis adalah Carol Ryff. Menurut Diener, kehidupan yang baik dijalani individu ketika ia sejahtera dari sudut pandang subjektifnya (Diener, 2000). Diener mengkonseptualisasikan kesejahteraan subjektif melalui 3 dimensi : (1) positive affect (afek positif), (2) negative affect (afek negatif), dan (3) life satisfaction (kepuasan hidup) (Diener, 1984). Sedangkan menurut Ryff, kehidupan yang baik dijalani individu ketika ia memiliki sejumlah kondisi yang membuatnya bisa berfungsi optimal sebagai manusia (Keyes, Shmotkin, \& Ryff, 2002). Ryff mengkonseptualisasikan kesejahteraan psikologis melalui 6 dimensi yaitu (1) Selfacceptance: mengacu pada pandangan positif terhadap diri dan penghargaan terhadap diri yang melibatkan afek positif maupun aspek negatif. Konsep ini mengacu pada penilaian yang jujur terhadap diri, sadar pada keterbatasan diri, namun tetap menerima diri sebagai pribadi; (2) Positive relation with others: Faktor ini meliputi rasa senang yang dialami saat memiliki hubungan dekat dengan orang lain; (3) Autonomy: Faktor ini mengacu pada kemampun individu untuk menentukan dan mengejar apa yang ia yakini, meskipun itu melawan dogma atau aturan yang ada; (4) Environmental mastery: Faktor ini mengacu pada tantangan dari lingkungan yang berhasil dikuasai oleh individu; (5) Purpose in life: Faktor ini mengacu pada kemampuan individu untuk menemukan makna dan arah dalam pengalaman pribadi dan untuk menentukan tujuan dalam 
hidupnya; (6) Personal growth: Faktor ini mengacu pada kemampuan individu untuk menyadari potensi dan bakatnya dan mengembangkan sumber daya baru (Ryff, 1989).

Teori kesejahteraan subjektif dan kesejahteraan psikologis memiliki persamaan dan perbedaan. Persamaannya adalah: (1) keduanya menggambarkan filosofi kehidupan yang baik; (2) keduanya didasari oleh pandangan psikologi positif yang bertujuan untuk menggali kekuatan dan kebaikan pada diri manusia; (3) keduanya memandang kesejahteraan individu dari perspektif psikologis. Sedangkan perbedaannya adalah: (1) sesuai dengan terminologinya, kesejahteraan subjektif menekankan pada penilaian subjektif individu. Artinya, konsep ini tidak bicara mengenai kondisi objektif individu tersebut, melainkan perasaan dan penilaian subjektif individu. Sedangkan kesejahteraan psikologis memiliki "standar objektif" yang ditetapkan oleh para ahli, berisi kemampuan-kemampuan yang harus dimiliki individu agar ia berfungsi secara optimal; (2) Kesejahteraan subjektif mengukur aspek emosi dan kognisi, sedangkan kesejahteraan psikologis mengukur aspek kognisi.

Perkembangan selanjutnya dari penelitian mengenai konsep kesejahteraan psikologis (KP) menunjukkan arah pemikiran yang melihat dua konsep ini (kesejahteraan subjektif dan kesejahteraan psikologis) sebagai konsep yang tidak terpisah. Secara filosofis, diyakini bahwa salah satu konsep saja kurang memadai untuk menggambarkan gagasan "kehidupan yang baik" dari manusia. Ryan \& Deci (2001) mengungkapkan bahwa well-being akan lebih baik jika dikonseptualisasikan sebagai fenomena multidimensional yang meliputi aspek hedonic dan eudaimonic. Secara empirik, beberapa penelitian menemukan bahwa kesejahteraan subjektif dan kesejahteraan psikologis merupakan konsep yang berbeda namun saling berhubungan dalam menjelaskan kesejahteraan manusia (Delle Fave, Brdar, Freire, Vella-Brodrick, \& Wissing, 2011; Keyes, Shmotkin, \& Ryff, 2002). Kesejahteraan subjektif dan kesejahteraan psikologis dipandang sebagai dua pendekatan penelitian dibandingkan dua konsep yang berbeda (Kashdan, Mishra, Breen, \& Froh, 2009). Ditegaskan oleh Kashdan, Biswasdiener, \& King (2008), bahwa kesejahteraan subjektif dan kesejahteraan psikologis merupakan dua variabel yang saling mempengaruhi dan tidak terpisah.

Penelusuran terhadap penelitian-penelitian yang mengkaji kesejahteraan psikologis pada usia remaja khususnya usia 12-15 tahun, menunjukkan bahwa pendekatan kesejahteraan subjektif dari Diener lebih banyak digunakan dibandingkan dengan pendekatan kesejahteraan psikologis dari Ryff (Bedin \& Sarriera, 2015; Casas et al., 2012; Levin,
Dallago, \& Currie, 2012; Newland et al., 2014; Proctor, Linley, \& Maltby, 2010; Saha, Huebner, Hills, Malone, \& Valois, 2014; Shek \& Lin, 2014; Sun \& Shek, 2012). Penelitian yang menggunakan terminologi psychological well-being pada umumnya menggunakan konsep yang dinilai memiliki pengertian yang sama, misalnya internalizing \& externalizing problems (Chen \& Liu, 2012); self-esteem, self-concept dan general self-efficacy (Okoiye, Nwoga, \& Thompson, 2015). Dalam proses konseptualisasinya, penelitian mengenai kesejahteraan psikologis anak dan remaja pada umumnya dilakukan melalui perspektif orang dewasa (Fattore, Mason, \& Watson, 2012). Cara ini berpotensi mengandung bias karena beberapa penelitian menemukan adanya perbedaan perspektif antara orang dewasa dengan anak/remaja dalam memandang kesejahteraan psikologis anak/remaja (Spilsbury, Korbin, \& Coulton, 2009). Penelitian yang mengkaji konsep kesejahteraan psikologis dari perspektif anak/remaja itu sendiri masih relatif terbatas, padahal sudut pandang remaja itu sendiri penting karena merupakan sumber informasi yang paling valid dan akurat (Vujcic, Zganec, \& Franc, 2019). Mengingat kajian mengenai konsep kesejateraan psikologis (KP) nantinya akan bermuara pada upaya peningkatannya, maka konseptualisasi yang akurat menjadi penting.

Penelusuran mengenai konsep yang digunakan oleh peneliti di Indonesia dalam mengkaji kesejahteraan psikologis (KP) remaja menunjukkan bahwa pada umumnya yang digunakan adalah konsep dari Barat, baik menggunakan tiga dimensi kesejahteraan subjektif dari Diener (1984) maupun menggunakan enam dimensi kesejahteraan psikologis dari Ryff (1989). Beberapa contohnya adalah penelitian Putri (2016) mengenai peran dukungan sosial dan kecerdasan emosi terhadap kesejahteraan subjektif pada remaja awal, penelitian Martin, Nuryoto, \& Urbayatun (2018) mengenai kaitan antara relaksasi dzikir dengan kesejahteraan subjektif remaja santri, penelitian Ramadhan (2012) mengenai kesejahteraan psikologis pada remaja santri penghafal Al-Quran, penelitian Harpan (2015) mengenai peran religiusitas dan optimisme terhadap kesejahteraan psikologis remaja, dan penelitian Prabowo (2016) mengenai kesejahteraan psikologis remaja di sekolah. Dari penelitian-penelitian tersebut terlihat bahwa alat ukur yang digunakan adalah alat ukur dari Barat yang bisa jadi tidak mengakomodasi aspek kultural yang khas dari konteks sosial di Indonesia. Alat ukur kesejahteraan psikologis pada remaja yang dikonseptualisasi melalui perspektif remaja pada konteks sosial Indonesia masih terbatas. Sebagai negara yang terletak di wilayah Asia Tenggara, Indonesia memiliki budaya yang berbeda dengan negara-negara yang berada di 
Barat. Perbedaan yang paling menonjol terlihat dalam dua hal, yaitu adanya hierarki dan budaya kolektif. Adanya hierarki mengharuskan anak untuk menghormati figur otoritas dan patuh pada orang tua (Chao \& Tseng, 2002; Yee, 1997). Budaya kolektif menekankan perlunya hidup yang harmonis dengan orang lain (Triandis, 1995). Berdasarkan adanya perbedaan budaya antara Indonesia dengan negara Barat, penelitian ini bertujuan untuk mengembangkan alat ukur kesejahteraan psikologis pada subjek remaja awal usia 12-15 tahun di Indonesia.

\section{METODE}

Penelitian ini menggunakan rancangan exploratory sequential mix method (Creswell, 2014). Pada rancangan ini, penelitian kualitatif dan kuantitatif dilakukan secara bertahap. Penelitian kualitatif dilakukan terlebih dahulu, lalu hasil analisis datanya digunakan pada penelitian kuantitatif sebagai tahap selanjutnya. Tahap penelitian kualitatif ditujukan untuk mengkonseptualisasi kesejahteraan psikologis remaja sebagai tahap pertama dari pengembangan alat ukur kesejahteraan psikologis remaja. Pada tahap kuantitatif, disusun alat ukur berdasarkan kesepuluh dimensi tersebut. Persetujuan etik untuk melakukan penelitian ini didapatkan dari Komisi Etik Penelitian Universitas Padjadjaran Bandung. Pada tahap penelitian kualitatif digunakan dua teknik pengambilan data, yaitu (1) wawancara individual semi terstruktur dan (2) focused group discussion (FGD). Wawancara dilakukan sebagai eksplorasi awal untuk menggali konsep dan dimensi-dimensi kesejahteraan psikologis pada konteks responden remaja Indonesia. FGD dilakukan untuk mendalami ruang lingkup dimensidimensi tersebut dalam kehidupan remaja usia 1215 tahun.

Subjek wawancara adalah remaja, orangtua, guru dan psikolog remaja. Selain remaja itu sendiri, orangtua dan guru dipilih karena merupakan orangorang dalam lingkungan terdekat remaja, sedangkan psikolog remaja dipilih sebagai profesional yang memahami dan memiliki pengalaman terkait dengan kesejahteraan psikologis remaja. Subjek berjumlah 11 orang, yaitu : (1) 3 orang remaja (1 orang perempuan usia 14 tahun, 1 orang laki-laki usia 15 tahun, 1 orang perempuan usia 15 tahun); (2) 3 orangtua remaja usia 12-15 tahun (1 ibu dari remaja perempuan berusia 14 tahun, 1 ibu dari remaja perempuan berusia 15 tahun, 1 ayah dari remaja laki-laki usia 15 tahun); (3) 2 guru SMP (1 guru SMP swasta, 1 guru SMP negeri ); (4) 3 Psikolog yang minimal berpraktek 5 tahun dalam menangani permasalahan anak dan remaja usia 12-15 tahun. Subjek ditanya mengenai gambaran kehidupan yang dinilai sejahtera secara psikologis pada remaja usia 12-15 tahun. Wawancara dilakukan secara individual oleh penulis pertama dalam rentang waktu masingmasing 45-60 menit. Hasil berupa rekaman wawancara kemudian dicatat secara verbatim. Pernyataan-pernyataan subjek dikategorikan ke dalam salah satu dari sembilan dimensi kesejahteraan psikologis, yaitu 3 dimensi kesejahteran subjektif dari Diener (1984) dan 6 dimensi kesejateraan psikologis dari Ryff (1989) (lihat di bagian pendahuluan). Tema-tema yang tidak dapat dikategorikan ke dalam salah satu dari 9 dimensi tersebut dikelompokkan menjadi tematema tertentu. Dalam proses analisanya, digunakan alat bantu software Nvivo 12 Pro. Dari kegiatan ini, didapatkan dimensi-dimensi kesejahteraan psikologis remaja usia 12-15 tahun.

Kegiatan kedua dari tahap kualitatif adalah focused group discussion. Subjek berjumlah 37 remaja usia 12-15 tahun (17 laki-laki, 20 perempuan; rata-rata usia $=13.10, \mathrm{SD}=0.87$ ) dari salah satu SMP negeri di Bandung. Subjek sebagian berasal dari suku Sunda (27 orang, $73 \%$ ), sisanya dari suku Jawa (4 orang, 11\%), serta suku Melayu dan Batak (masing-masing 3 orang, 8\%). Ke-37 subjek dibagi ke dalam 6 kelompok, jumlah subjek dalam satu kelompok antara 5 sampai 7 orang. Pada masing-masing kelompok, diskusi dipimpin oleh dua asisten peneliti yang berperan sebagai fasilitator (fasilitator utama adalah psikolog anak/remaja, fasilitator pendamping adalah mahasiswa magister psikolog anak/remaja). Fasilitator telah mendapatkan pelatihan sebelumnya terkait konsep kesejahteraan psikologis (KP) dan hasil wawancara. Alat ukur pada tahap ini berupa panduan FGD (focus group discussion); dengan pertanyaan utama: "Bagaimana pengalaman subjek mengenai 10 dimensi kesejahteraan psikologis yang sudah diidentifikasi dari hasil wawancara?" (didiskusikan pendapat dan pengalamannya, satu persatu pada tiap dimensi). Diskusi didokumentasikan menggunakan alat bantu perekam audio. Hasil rekaman diskusi dicatat secara verbatim untuk dianalisis. Pencatat adalah asisten peneliti (fasilitator) yang mengambil data pada sesi diskusi yang bersangkutan. Hasil rekaman berupa catatan verbatim diolah oleh tim peneliti menggunakan teknik thematic analysis dengan bantuan software Nvivo 12 Pro. Masing-masing pernyataan dimasukkan ke dalam sembilan kategori dimensi yaitu (1) afek positif, (2) afek negatif, (3) kepuasan hidup, (4) penerimaan diri, (5) hubungan positif dengan orang lain, (6) otonomi, (7) penguasaan lingkungan, (8) tujuan hidup, dan (9) pengembangan pribadi. Sejumlah jawaban responden yang tidak bisa dikategorisasikan pada salah satu dimensi di atas, dikelompokkan menjadi 
dimensi tersendiri. Proses analisa data didiskusikan antar tim penulis.

Pada tahap kuantitatif, untuk melanjutkan konseptualisasi yang telah dilakukan melalui studi kualitatif disusun alat ukur kesejahteraan psikologis remaja mengikuti tahapan test construction, test tryout, item analysis, dan test revision (Cohen \& Swerdlik, 2009). Pada tahap test construction, itemitem alat ukur ditulis lalu diberikan pada dua orang ahli (akademisi yang area penelitiannya adalah kesejahteraan psikologi (KP) untuk ditelaah. Adapun poin telaah terdiri dari dua hal: (1) ketepatan penurunan definisi masing-masing dimensi ke dalam item, (2) kualitas redaksi item dalam tiga hal: relevant, important, clarity (Cohen \& Swerdlik, 2009). Pada tahap test tryout, alat ukur diujicobakan pada kelompok subjek remaja dari salah satu SMP Negeri di Kota Bandung, dengan kriteria usia 12-15 tahun, memahami bahasa Indonesia dan tidak mengalami gangguan perkembangan (misal ADHD, autism, intellectual disability). Karena kesimpulan yang akan didapatkan melalui penelitian kuantitatif ini adalah keterandalan instrumen pengukuran, maka subjek dapat dijaring dengan menggunakan convenient sampling (Triwahyuni, Purwono, Sadarjoen, \& Sapri, 2019). Data yang didapatkan lalu diolah pada tahap item analysis. Pada tahap ini, validitas itemitemnya dihitung menggunakan standardized loading estimates. Nilai minimal yang diharapkan adalah 0,40 dengan nilai t yang signifikan (Wang, Andrade, \& Gorenstein, 2005). Jika item-item belum memiliki validitas yang memadai, maka dilakukan revisi dan dilakukan uji coba kembali (test conceptualization), sampai mendapatkan sejumlah item yang valid. Selanjutnya, reliabilitas dan validitas alat ukur dapat dihitung. Reliabilitas dilakukan menggunakan perhitungan internal consistency yaitu Cronbach's coefficient alpha. Reliabilitas yang diharapkan adalah diatas angka 0,70 (Hair Jr, William, Babin, \& Anderson, 2014). Analisanya menggunakan software IBM Statistics SPSS 22. Bukti validitas menggunakan validitas struktur internal melalui confirmatory factor analysis. Kriteria fit model menggunakan GFI sebagai absolute fit index, NFI sebagai incremental fit index, CFI sebagai goodness-of-fit index, dan RMSEA sebagai badness-of-fit index. Kriteria standar nilai fit yang digunakan adalah minimal 0,90 untuk GFI, NFI, and CFI, serta kurang dari 0,08 untuk RMSEA (Hair Jr et al., 2014). Analisa CFA menggunakan Lisrel Software Version 9.30.

\section{HASIL DAN PEMBAHASAN}

\section{Hasil Penelitian Kualitatif}

Olahan data wawancara mendapatkan hasil sebagai berikut:
(1) Jawaban subjek penelitian menunjukkan kesejahteraan psikologis remaja usia 12-15 tahun mengandung sebagian elemen kesejahteraan subjektif dari Diener (1984) dan sebagian elemen kesejahteraan psikologis dari Ryff (1989).

(2) Elemen kesejahteraan subjektif yang ditemukan dari jawaban subjek adalah afek positif dan afek negatif. Dimensi life satisfaction tidak ditemukan dari jawaban reponden.

(3) Elemen kesejahteraan psikologis yang ditemukan dari jawaban subjek adalah positive relation with other, self-acceptance, personal growth, purpose in life. Tidak ada jawaban subjek yang dapat dikategorikan ke dalam aspek autonomy dan environmental mastery,

(4) Terdapat sejumlah jawaban yang tidak bisa dikategorisasikan pada salah satu elemen kesejahteraan subjektif maupun kesejahteraan psikologis. Tim peneliti mengkategorisasikannya menjadi empat tema:

a. Pengelolaan emosi

"Udah bisa ngontrol diri kalau dari emosional, udah bisa ngejaga” (AR, Remaja).

"Kalau lagi marah tidak melakukan tindakan-tindakan yang istilahnya diluar kewajaran dia atau dia punya pelampiasan sendiri" (CP, orangtua).

"Bisa aware terhadap emosinya..." (MAY, Psikolog).

b. Tanggung jawab

"Kalau dia udah ngerti tanggung jawab jadi udah ngerti yang terbaiknya bagi dirinya" (DA, Remaja).

"Terus tapi dia juga sudah mulai menyadari tugasnya. Bukan belajar nilai bagusnya ya, tapi dia udah menyadari dia punya tugas, tugas beban belajar gitu” (NW, orangtua).

"Dia udah tanggung jawab, dia tau ini waktunya solat.. kayak gitu..” (MS, Guru).

c. Kemampuan menyelesaikan masalah "Jadi udah bisa dilepas lah kalau ada masalah, gak selalu tergantung gitu ...” (AR, Remaja)

"Ya dia bisa walaupun dalam keadaan tidak enak ya, dia bisa mencari yang membuat dia enak gitu. Kayak misalnya dia merasa dia tidak happy dengan di sekolah, atau di mana, dia mengalihkan ke hobinya, dengan menggambar, atau dengar musik, atau ya baca buku." (NW, Orangtua)

"Ketika muncul konflik dengan teman ya tidak mudah menyerah, tau gimana menyelesaikannya" (AS, Psikolog)

d. Harmoni

"Yang bisa bergaul sama temen-temen terus pelajarannya juga bagus” (EH, Remaja) 
"Yang sangat menonjol di salah satu, misalnya pinter banget tapi ditolak sama temen-temennya, atau gak mau bantuin orangtua di rumah, itu engga" (IA, Orangtua)

"Seimbang. Yang seimbang itu lebih sejahtera...seimbang segala aspek kehidupannya" (LAD, Guru)

Dengan demikian, dari tahap ini didapatkan 10 dimensi kesejahteraan psikologis remaja usia 12-15 tahun : (1) positive affect (afek positif), (2) negative affect (afek negatif), (3) self-acceptance (penerimaan diri), (4) positive relation with other (hubungan positif), (5) purpose in life (tujuan hidup) (6) personal growth (pengembangan diri), (7) pengelolaan emosi, (8) tanggung jawab, (9) kemampuan menyelesaikan masalah, (10) harmoni. Hasil focused group discussion adalah definisi konseptual dari masing-masing dimensi, sebagai berikut:

(1) Afek positif: perasaan-perasaan positif yang dirasakan remaja mengenai kehidupannya.

(2) Afek negatif: perasaan-perasaan negatif yang dirasakan remaja mengenai kehidupannya.

(3) Kepercayaan diri: pandangan positif dan kepercayaan remaja terhadap dirinya.

(4) Hubungan positif: kualitas diri untuk menjalin hubungan dengan teman dan guru.

(5) Orientasi masa depan: kemampuan untuk memikirkan masa depan remaja dalam bidang akademik dan pekerjaan.

(6) Pengembangan diri: kemampuan remaja untuk menyadari potensi dan bakatnya serta mengembangkan diri.

(7) Pengelolaan emosi negatif: kemampuan untuk mengenali emosi negatif dan menahan diri untuk tidak melakukan perilaku yang dianggap negatif oleh norma.

(8) Tanggung jawab: kemampuan untuk melaksanakan kewajiban di rumah dan beribadah.

(9) Kemampuan menyelesaikan masalah: kemampuan untuk menyelesaikan masalah secara mandiri dan meminta bantuan pada orang yang tepat jika membutuhkannya.

(10) Harmoni: keseimbangan antara prestasi akademik dan pertemanan, serta antara keluarga dan teman.

Afek positif dan negatif adalah elemen dari kesejahteraan subjektif. Definisi konseptual dari afek positif dan afek negatif dari hasil penelitian ini sama dengan definisi dari Diener (1984), yaitu perasaan-perasaan (positif/negatif) yang dirasakan individu (dalam hal ini remaja usia 12-15 tahun) mengenai kehidupannya. Dua dimensi yang pada awalnya (hasil wawancara) mengacu pada dimensidimensi kesejahteraan psikologis dari Ryff (1989) mengalami modifikasi dalam nama dan definisi konseptualnya, yaitu dimensi self-acceptance (penerimaan diri) yang berubah menjadi kepercayaan diri, dan purpose in life (tujuan hidup) yang berubah menjadi orientasi masa depan. Sedangkan untuk dimensi positive relation with other (hubungan positif), dan personal growth (pengembangan diri), hanya definisinya yang berubah. Secara umum, modifikasi tersebut bersifat lebih kontekstual sesuai dengan tahap perkembangan remaja usia 12-15 tahun.

Hasil penelitian yang menunjukkan bahwa konsep kesejahteraan psikologis remaja terdiri dari elemen-elemen kesejahteraan subjektif dan elemenelemen kesejahteraan psikologis secara simultan mendukung paradigma mutakhir terkait konsep kesejahteraan psikologi (KP) (Delle Fave et al., 2011; Kashdan et al., 2008, 2009; Keyes et al., 2002). Remaja usia 12-15 tahun menilai dirinya sejahtera secara psikologis tidak hanya apabila ia merasakan emosi positif dan tidak merasakan emosi negatif (elemen hedonic/ kesejahteraan subjektif), namun juga apabila diri mereka berfungsi secara optimal sesuai dengan tahap perkembangannya (elemen eudaimonic/ kesejahteraan psikologis). Dari penelitian ini, fungsi diri yang optimal dirasakan remaja usia 12-15 tahun adalah saat ia percaya pada dirinya, memiliki hubungan positif dengan guru dan teman, memiliki pemikiran masa depan terkait akademik dan pekerjaan, menyadari potensi dan bakatnya, mampu mengenali dan mengelola emosi negatif, memiliki tanggung jawab terhadap kewajiban di rumah dan beribadah, bisa menyelesaikan masalah dan mengetahui pada siapa ia bisa meminta pertolongan, serta bisa menyeimbangkan antara aspek akademik dan non akademik, juga antara keluarga dan teman. Artinya, remaja usia 12-15 tahun sudah punya "sense of functioning”, baik untuk saat ini (mengembangkan diri) maupun untuk masa depan (orientasi masa depan) (Huppert, 2009). Jika dilihat dari karakteristiknya, memang remaja usia 12-15 tahun sudah bisa berpikir abstrak dan melakukan refleksi diri (Steinberg \& Morris, 2001).

Terdapat beberapa kesamaan antara hasil penelitian ini dengan penelitian serupa yang dilakukan oleh Vujcic, Zganec, \& Franc (2019) pada remaja di Kroasia dan penelitian Exenberger, Banzer, Christy, Höfer, \& Juen (2019) yang mengeksplorasi konsep kesejahteraan psikologis pada remaja di India dan Eropa. Kesamaannya terletak pada konseptualisasi kesejahteraan psikologi (KP) sebagai konsep yang multidimensional. Selain itu dari kedua penelitian tersebut ditemukan juga hasil bahwa dimensi kesejahteraan psikologis (KP) yang dikonseptualisasikan oleh remaja terkait erat dengan aspek relasi dengan keluarga, teman dan sekolah. Aspek relasi dengan teman dan sekolah pada penelitian ini terlihat pada dimensi hubungan positif yang spesifik mengacu pada teman dan guru, 
sedangkan relasi dengan keluarga terlihat dari dimensi tanggung jawab yang melibatkan kewajiban di rumah serta adanya harmoni antara keluarga dan teman. Dari dimensi tanggung jawab dan harmoni, tersirat karakteristik khas dari selfconstrual individu yang berada dalam kultur collectivist, yaitu adanya kepatuhan dari anak dan pandangan mengenai pentingnya keseimbangan dan harmonisasi antara hal-hal yang dianggap penting oleh remaja (Tamis-lemonda, Way, Hughes, York, \& Niwa, 2007).

Adanya tema "akademik" (pada dimensi harmoni) sama-sama ditemukan pada remaja yang berada dalam kultur individualist maupun pada remaja yang berada dalam kultur collectivist. Bedanya, pada remaja dengan kultur individualist (Eropa), prestasi akademik merupakan aspek penting terkait elemen sekolah. Sedangkan pada remaja dengan kultur collectivist, yang dipentingkan bukan prestasi, namun "koneksi interpersonalnya" (misalnya berprestasi untuk menyenangkan orangtua, atau belajar karena menuruti perintah guru) (Exenberger et al., 2019). Ciri pengaruh kultur collectivist tampak dari hasil penelitian ini, pada aspek tanggung jawab, yaitu patuh mengerjakan tugas di rumah dan keseimbangan antara akademik-non akademik. Pada aspek harmoni, terlihat juga ada tema keseimbangan antara relasi dengan orangtua versus relasi dengan teman. Hal ini merupakan tema khas perkembangan remaja usia 12- 15 tahun, dimana anak masih memiliki hubungan kuat dengan orangtua dan ingin patuh di satu sisi, tapi memiliki dorongan kuat juga untuk menjalin relasi dan mengeksplorasi hal-hal baru bersama teman. Konflik antara kedua kebutuhan menjadi ciri khas perkembangan remaja di usia ini (Crosnoe \& Johnson, 2011).

Ada satu hal yang menjadi keunikan hasil temuan tahap kualitatif ini dibandingkan dengan penelitian serupa, yaitu adanya aspek religiusitas yang masuk ke dalam dimensi tanggung jawab (menjalankan ibadah). Temuan ini dapat dijelaskan melalui tujuan pengasuhan orangtua di Indonesia, yang menekankan pada aspek religiusitas khususnya menjalankan kewajiban beribadah (Abidin, Siregar, Joefiani, \& Koesma, 2017).

\section{Hasil Penelitian Kuantitatif}

Hasil penelitian kualitatif mengenai konsep kesejahteraan psikologis remaja usia 12-15, sekaligus tahap pertama dalam pengembangan alat ukur kesejahteraan psikologis remaja usia 12-15 tahun, yaitu tahap konseptualisasi (test conceptualization). Pada tahap ini juga dirumuskan bentuk alat ukur yang akan disusun, pengadministrasian dan cara skoringnya. Alat ukur ini berbentuk skala likert, dengan 6 pilihan jawaban: Sangat-Sangat Tidak Sesuai (SSTS), Sangat Tidak Sesuai ( STS), Tidak Sesuai (TS), Sesuai (S), Sangat Sesuai (SS), dan Sangat-Sangat Sesuai (SSS). Alat ukur ini bisa diadministrasikan secara individual maupun kelompok dengan bentuk paper and pencil menggunakan lembar jawab komputer (LJK). Skoring alat ukur ini dilakukan dengan cara mengkuantifikasikan jawaban subjek, sebagai berikut : Sangat-Sangat Tidak Sesuai (SSTS) dicatat sebagai skor 1, Sangat Tidak Sesuai (STS) skor 2, Tidak Sesuai (TS) skor 3, Sesuai (S) skor 4, Sangat Sesuai (SS) skor 5, dan SangatSangat Sesuai (SSS) skor 6. Cara skoring tersebut berlaku untuk item positif. Sedangkan untuk item negatif, cara skoringnya dibalik. Skor total dimensi dan skor total alat ukur ini didapatkan dengan menggunakan cummulative model, artinya semakin tinggi skor dari alat ukur ini, menunjukkan semakin tinggi kesejahteraan psikologis remaja.

Pada tahap konstruksi (test construction), peneliti menulis 109 item. Target jumlah item final adalah 3 sampai 5 item per dimensi, artinya total 3050 item. Jumlah item yang disusun tiga kali lebih banyak dibandingkan dengan jumlah item final yang diharapkan, dimaksudkan agar apabila dalam proses ujicoba ada sebagian item yang validitas itemnya rendah, maka item sisanya masih bisa digunakan. Seratus sembilan item tersebut kemudian diserahkan pada dua orang ahli untuk ditelaah. Ahli penelaah menilai masing-masing item secara kualitatif dalam hal: (1) ketepatan penurunan definisi masing-masing dimensi ke dalamitem, (2) kualitas redaksi item dalam tiga hal: relevant, important, clarity. Hasil berupa komentar dari ahli kemudian direkap dan didiskusikan oleh tim peneliti. Pada akhir proses ini, jumlah item berkurang menjadi 86 . Item-item yang dinilai tidak tepat penurunannya dari dimensi dan atau tidak memenuhi ktiteria relevant, important dan clarity tidak diikutsertakan.

Ke-86 item tersebut kemudian diujicobakan (test tryout) pada 494 subjek penelitian, yang terdiri dari 240 orang laki-laki $(48,6 \%)$ dan 254 perempuan $(51,4 \%)$. Rentang usia subjek adalah $12-15$ tahun $(\mathrm{x}=13,61, \mathrm{SD}=0,93)$, terdiri dari siswa kelas 7, 8 dan 9. Analisis dilakukan untuk menghitung validitas item (item analysis), menggunakan CFA. Dari hasil analisa, hanya 56 item yang memiliki validitas memadai (factor loading diatas 0,4). Ke-56 item kemudian diujicobakan lagi pada 297 subjek penelitian, yang terdiri dari 141 orang laki-laki $(47,5 \%)$ dan 156 perempuan $(52,5 \%)$. Rentang usia subjek adalah 12-15 tahun $(\mathrm{x}=13,70, \mathrm{SD}=0,87)$, terdiri dari siswa SMP kelas 7, 8 dan 9. Dari uji coba kedua ini didapatkan 38 item yang validitasnya memadai. Proses penyusunan alat ukur secara visual digambarkan pada bagan 1 . 


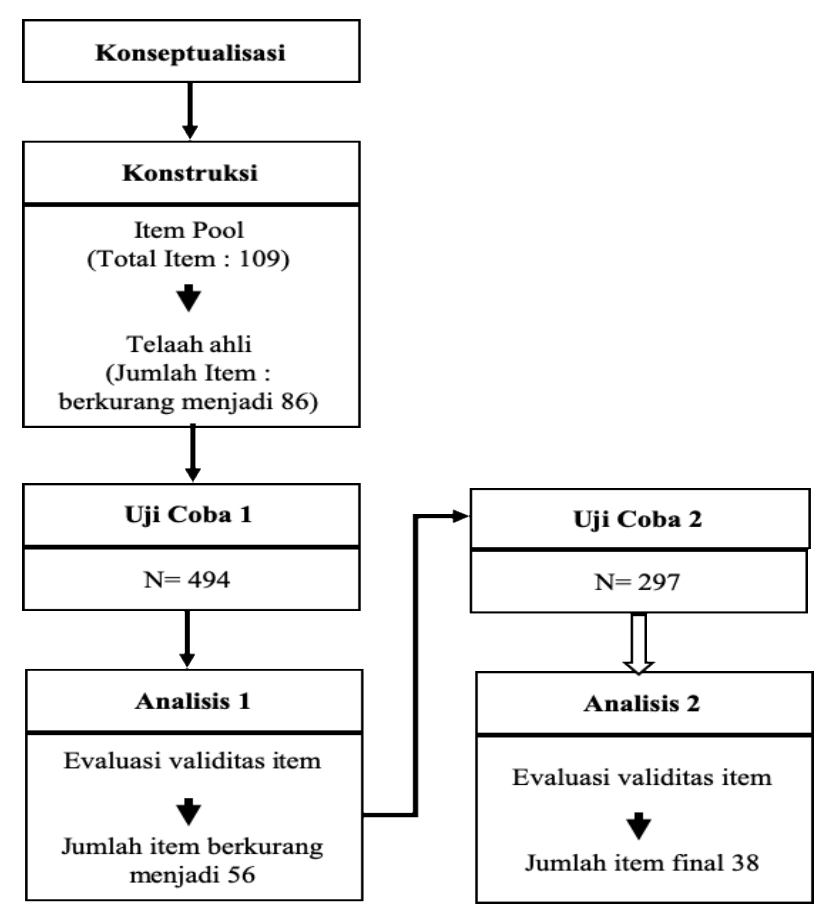

Bagan 1. Proses Penyusunan Alat Ukur Kesejahteraan Psikologis Remaja Usia 12-15 Tahun

Dari 38 item tersebut, ada dua item yang validitas itemnya di bawah 0,4 . Dua item tersebut tetap diikutsertakan dengan pertimbangan jumlah item pada setiap dimensi adalah minimal 3 . Rekapitulasinya dapat dilihat di tabel 1 .

Tabel 1. Jumlah item dan rentang loading factor dari dimensi-dimensi kesejahteraan psikologis remaja usia 12-15 tahun.

\begin{tabular}{lcc}
\hline \multicolumn{1}{c}{ Dimensi } & $\begin{array}{c}\text { Jumlah } \\
\text { Item }\end{array}$ & $\begin{array}{c}\text { Loading } \\
\text { Factor }\end{array}$ \\
\hline Afek Positif & 5 & $0,74-0,89$ \\
Afek Negatif & 5 & $0,63-0,82$ \\
Kepercayaan diri & 3 & $0,52-0,73$ \\
Hubungan positif & 5 & $0,42-0,76$ \\
$\begin{array}{l}\text { Orientasi masa depan } \\
\text { Pengembangan diri }\end{array}$ & 3 & $0,81-0,83 ;$ \\
$\begin{array}{l}\text { Pengelolaan emosi } \\
\text { negatif }\end{array}$ & 4 & $0,45-0,66$ \\
$\begin{array}{l}\text { Tanggung jawab } \\
\begin{array}{l}\text { Kemampuan } \\
\text { menyelesaikan masalah }\end{array}\end{array}$ & 3 & $0,63-0,69 ;$ \\
\end{tabular}

\begin{tabular}{lcc}
\hline Harmoni & 3 & $0,51-0,78$ \\
Total & 38 & \\
\hline
\end{tabular}

Selanjutnya, dihitung reliabilitas dan validitas dari alat ukur. Reliabilitas menggunakan internal consistency mencapai $\alpha=0,873$. Validitas konstruk alat ukur ini memenuhi kriteria Goodness of fit $(\mathrm{RMSEA}=0,075 ; \mathrm{GFI}=0,91 ; \mathrm{CFI}=0,93 ; \mathrm{NNFI}=$ $0,91$; IFI $=0,93)$, dengan model pengukuran tergambar di bagan 2 .

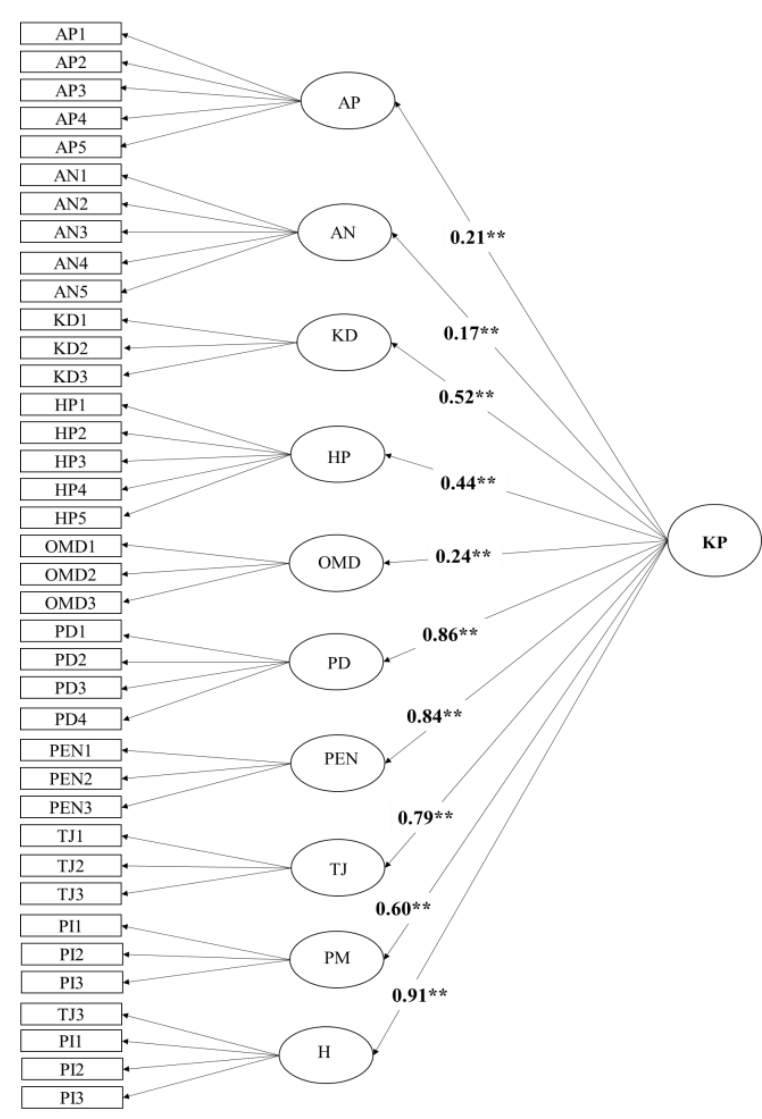

Bagan 2 Model Pengukuran Alat Ukur Kesejahteraan Psikologis Remaja Usia 12-15 Tahun

Dengan hasil perhitungan analisis item, reliabilitas dan validitas di atas, dapat dikatakan bahwa alat ukur kesejahteraan psikologis remaja usia 12-15 tahun yang disusun dalam penelitian ini valid dan reliabel untuk digunakan. Dengan demikian, dapat menjadi alternatif alat untuk digunakan mengukur kesejahteraan psikologis (KP) remaja usia 12-15 tahun. Perlu digarisbawahi bahwa kelebihan dari alat ukur ini adalah dalam konteksnya yang spesifik, yaitu pada konteks tahap perkembangan remaja usia 12-15 tahun di Indonesia yang bersekolah di jenjang pendidikan $\mathrm{SMP} /$ sederajat. Konteks yang spesifik ini membuat 
hasil pengukurannya bisa memberikan gambaran dimensi apa yang perlu ditingkatkan secara konkrit oleh pihak-pihak yang terkait. Kelebihan ini juga sekaligus menjadi kekurangan dalam hal keterbatasan penggunaan alat ukur ini pada kelompok di luar remaja usia 12-15 tahun dan di luar remaja yang bersekolah formal.

Terdapat beberapa keterbatasan dalam penelitian ini, yang bisa menjadi peluang untuk penelitian selanjutnya. Keterbatasan pertama pada abstraknya istilah "well-being/kesejahteraan psikologis". Untuk bisa menjelaskan konsep ini terutama pada tahap wawancara, diberikan penjelasan lebih lanjut pada subjek orangtua, anak dan guru untuk bisa menangkap maksud dari konsep ini dengan tepat. Ke depannya, peneliti di bidang kesejahteraan psikologis dapat merumuskan suatu terminologi sebagai padanan kata wellbeing/kesejahteraan psikologis yang bisa lebih mudah dipahami maknanya oleh masyarakat umum. Keterbatasan kedua, pada focused group discussion (FGD), subjek saling mengenal sehingga dalam mengemukakan gagasan dan pengalamannya menjadi saling mempengaruhi. Penelitian selanjutnya sebaiknya melakukan juga wawancara pada subjek FGD, sehingga pendapat dan pengalaman personal bisa digali tanpa terpengaruh pendapat dan pengalaman rekan-rekannya. Keterbatasan ketiga, reliabilitas dan validitas alat ukur ini hanya menggunakan masing-masing satu metode. Alat ukur kesejahteraan psikologis remaja usia 12-15 tahun hasil penelitian ini dapat dikaji kembali untuk dilengkapi bukti psikometriknya menggunakan metoda reliabilitas dan validitas yang lebih beragam.

\section{SIMPULAN}

Hasil penelitian ini menunjukkan bahwa alat ukur kesejahteraan psikologis remaja yang terdiri dari 10 dimensi yaitu afek positif, afek negatif, kepercayaan diri, hubungan positif, orientasi masa depan, pengembangan diri, pengelolaan emosi negatif, tanggung jawab, kemampuan menyelesaikan masalah, dan harmoni merupakan alat ukur yang valid dan reliabel untuk mengukur derajat kesejahteraan psikologis remaja usia 12-15 tahun di Indonesia. Dengan mempertimbangkan aspek psikologis-sosial kontekstual, maka dalam tataran teoretis, peneliti kesejahteraan psikologis di Indonesia perlu melakukan kajian kritis saat akan mengukur kesejahteraan psikologis, terlebih apabila menggunakan alat ukur yang dikonstruksi dari subjek yang berbeda tahap perkembangannya dari subjek yang akan teliti, serta dikonstruksi dari budaya yang berbeda dengan Indonesia. Dalam tataran aplikatif, mempertimbangkan pentingnya kesejahteraan psikologis pada remaja sebagai dasar berkembangnya individu dewasa yang berfungsi optimal, maka keakuratan konsep dan hasil pengukuran menjadi faktor penting yang harus diperhatikan. Jika alat ukur dan hasil pengukurannya mendekati akurasi realitas sesungguhnya di lapangan, maka hasil pengukuran bisa menjadi asesemen akurat yang bisa ditindaklanjuti dalan bentuk intervensi.

\section{UCAPAN TERIMA KASIH}

Peneliti mengucapkan terima kasih kepada Lembaga Pemberi Dana Pendidikan (LPDP) yang telah memberikan beasiswa program doktor pada peneliti sehingga penelitian ini dapat dilakukan. Terima kasih juga peneliti sampaikan pada Dr. Retno Hanggarini Ninin, M.Psi Psikolog dan Aulia Iskandarsyah, M.Si, M.Sc, $\mathrm{PhD}$ yang telah bersedia menjadi penelaah ahli dalam proses penyusunan alat ukur.

\section{DAFTAR PUSTAKA}

Abidin, F. A., Siregar, J. R., Joefiani, P., \& Koesma, R. E. (2017). Parenting Goals among Moslem Parents in Bandung, Indonesia. In Advances in Social Science (Vol. 58, pp. 225-227). Atlantic Press.

Akhtar, M. (2009). Applying Positive Psychology to Alcohol-Misusing Adolescents : A Pilot Intervention. University of East London.

Bedin, L. M., \& Sarriera, J. C. (2015). A comparative study of the subjective wellbeing of parents and adolescents considering gender, age and social class. Social Indicators Research, 120(1), 79-95. https://doi.org/10.1007/s11205-014-0589-7

Casas, F., Coenders, G., González, M., Malo, S., Bertran, I., \& Figuer, C. (2012). Testing the Relationship Between Parents' and Their Children's Subjective Well-Being. Journal of Happiness Studies, 13(6), 1031-1051. https://doi.org/10.1007/s10902-011-9305-3

Chao, R. K., \& Tseng, V. (2002). Parenting of Asian. In M. H. Bornstein (Ed.), Handbook of Parenting : Social Conditions and Applied Parenting (2nd editio, Vol. 4, pp. 59-94). New Jersey: Lawrence Erlbaum Associates, Inc.

Cohen, R. J., \& Swerdlik, M. E. (2009). Psychological Testing and Assessment: An Introduction to Tests and Measurement (3rd ed.). (7th Editio). McGraw-Hill. Retrieved from http://www.primisonline.com

Creswell, J. W. (2014). Research Design : Qualitative, Quantitative, and Mixed Methods Approaches (4th Editio). 
California: Sage Publications.

Crosnoe, R., \& Johnson, M. K. (2011). Research on Adolescence in the Twenty_First Century. Annual Review Sociology, 37, 439460. https://doi.org/10.1146/annurev-soc081309-150008.Research

Delle Fave, A., Brdar, I., Freire, T., VellaBrodrick, D., \& Wissing, M. P. (2011). The Eudaimonic and Hedonic Components of Happiness: Qualitative and Quantitative Findings. Social Indicators Research, 100(2), 185-207. https://doi.org/10.1007/s11205-010-9632-5

Diener, E. (1984). Subjective Well-Being. Psychological Bulletin, 95(3), 542-575.

Diener, E. (2000). Subjective Well-Being. American Psychologist, 55(1). https://doi.org/10.1037//0003-066X.55.1.34

Exenberger, S., Banzer, R., Christy, J., Höfer, S., \& Juen, B. (2019). Eastern and Western Children's Voices on their Well-Being. Children Indicator Research, 12, 747-768.

Fattore, T., Mason, J., \& Watson, E. (2012). Locating the Child Centrally as Subject in Research : Towards a Child Interpretation of Well-Being. Child Indicators Research, 5, 423-435. https://doi.org/10.1007/s12187012-9150-X

Hair Jr, J. F., William, C., Babin, B. J., \& Anderson, R. E. (2014). Multivariate Data Analysis (Seventh Ed). Harlow: Pearson.

Harpan, A. (2015). Peran Religiusitas dan Optimisme terhadap Kesejahteraan Psikologis pada Remaja. Empathy, 3, 1-18. Retrieved from http://journal.uad.ac.id/index.php/EMPATH Y/article/view/3198/1802

Heryanah. (2015). Ageing Population dan Bonus Demografi Kedua di Indonesia. Populasi, 23(2), 1-16. https://doi.org/10.22146/jp.15692

Huppert, F. A. (2009). Psychological Well-being : Evidence Regarding its Causes and Consequences $\uparrow$. Applied Psychology: Health and Well-Being, 1(2), 137-164. https://doi.org/10.1111/j.17580854.2009.01008.x

Kashdan, T. B., Biswas-diener, R., \& King, L. A. (2008). Reconsidering happiness : the costs of distinguishing between hedonics and eudaimonia. The Journal of Positive Psychology, 3(4), 219-233. https://doi.org/10.1080/17439760802303044

Kashdan, T. B., Mishra, A., Breen, W. E., \& Froh, J. J. (2009). Gender differences in gratitude: Examining appraisals, narratives, the willingness to express emotions, and changes in psychological needs. Journal of Personality, 77(3), 691-730. https://doi.org/10.1111/j.1467-

6494.2009.00562.x

Keyes, C. L. M., Shmotkin, D., \& Ryff, C. D. (2002). Optimizing well-being: The empirical encounter of two traditions. Journal of Personality and Social Psychology, 82(6), 1007-1022. https://doi.org/10.1037/0022-3514.82.6.1007

Khan, Y., Taghdisi, M. H., \& Nourijelyani, K. (2015). Psychological Well-Being (PWB) of School Adolescents Aged 12-18 yr, its Correlation with General Levels of Physical Activity (PA) and Socio-Demographic Factors In Gilgit, Pakistan. Iranian Journal of Public Health, 44(6), 804-813. https://doi.org/10.4049/jimmunol.0903113

Levin, K. A., Dallago, L., \& Currie, C. (2012). The Association Between Adolescent Life Satisfaction, Family Structure, Family Affluence and Gender Differences in ParentChild Communication. Social Indicators Research, 106(2), 287-305. https://doi.org/10.1007/s11205-011-9804-y

Martin, I., Nuryoto, S., \& Urbayatun, S. (2018). Relaksasi dzikir untuk meningkatkan kesejahteraan subjektif remaja santri. Psikis : Jurnal Psikologi Islami, 4(2), 112-123.

Newland, L. A., Giger, J. T., Lawler, M. J., Carr, E. R., Dykstra, E. A., \& Roh, S. (2014). Subjective Well-Being for Children in a Rural Community. Journal of Social Service Research, 40(5), 642-661. https://doi.org/10.1080/01488376.2014.9174 50

Prabowo, A. (2016). Kesejahteraan Psikologis Remaja di Sekolah. Jurnal Ilmiah PSikologi Terapan, 04(02), 31-48.

Proctor, C., Linley, P. A., \& Maltby, J. (2009). Youth life satisfaction measures : a review. The Journal of Positive Psychology, 4(2), 128-144. https://doi.org/10.1080/17439760802650816

Proctor, C., Linley, P. A., \& Maltby, J. (2010). Very Happy Youths: Benefits of Very High Life Satisfaction Among Adolescents. Social Indicators Research, 98(3), 519-532. https://doi.org/10.1007/s11205-009-9562-2

Putri, D. R. (2016). Peran dukungan sosial dan kecerdasan emosi terhadap kesejahteraan subjektif pada remaja awal. Jurnal Indigenous, 1(1), 12-22.

Ramadhan, Y. A. (2012). Kesejahteraan Psikologis Pada Remaja Santri Penghafal Al-Quran. Psikologika, 17(1), 27-38.

Ryan, R. M., \& Deci, E. L. (2001). On Happiness and Human Potentials : A Review of Research on Hedonic and Eudaimonic WellBeing. Annual Review of Psychology, 52, 
141-166.

Ryff, C. D. (1989). Happiness is everything, or is it? Explorations on the meaning of psychological well-being. Journal of Personality and Social Psychology, 57(6), 1069-1081. https://doi.org/10.1037/00223514.57.6.1069

Ryff, C. D., Love, G. D., Urry, H. L., Muller, D., Rosenkranz, M. A., Friedman, E. M., ... Singer, B. (2006). Psychological Well-Being and Ill-Being: Do They Have Distinct or Mirrored Biological Correlates?

Psychotherapy and Psychosomatics, 75, 8595. https://doi.org/10.1159/000090892

Saha, R., Huebner, E. S., Hills, K. J., Malone, P. S., \& Valois, R. F. (2014). Social Coping and Life Satisfaction in Adolescents. Social Indicators Research, 115(1), 241-252. https://doi.org/10.1007/s11205-012-0217-3

Shek, D. T. L., \& Lin, L. (2014). Personal WellBeing and Family Quality of Life of Early Adolescents in Hong Kong: Do Economic Disadvantage and Time Matter? Social Indicators Research, 117(3), 795-809. https://doi.org/10.1007/s11205-013-0399-3

Spilsbury, J. C., Korbin, J. E., \& Coulton, C. J. (2009). Mapping Children's Neighborhood Perceptions : Implications for Child Indicators. Child Indicators Research, 2, 111-131. https://doi.org/10.1007/s12187009-9032-z

Steinberg, L., \& Morris, A. S. (2001). Adolescent Development. Annual Review of Psychology, 52, 83-110. Retrieved from www.annualreviews.org

Sun, R. C. F., \& Shek, D. T. L. (2012). Positive Youth Development, Life Satisfaction and Problem Behaviour Among Chinese Adolescents in Hong Kong: A Replication. Social Indicators Research, 105(3), 541559. https://doi.org/10.1007/s11205-0119786-9

Tamis-lemonda, C. S., Way, N., Hughes, D., York, N., \& Niwa, E. Y. (2007). Parents' Goals for Children : The Dynamic Coexistence of Individualism and Collectivism in Cultures and Individuals. https://doi.org/10.1111/j.14679507.2007.00419.x

Triandis, H. C. (1995). Individualism and Collectivism. Westview: Boulder,Co.

Triwahyuni, A., Purwono, U., Sadarjoen, S. S., \& Sapri, E. R. (2019). PENGEMBANGAN MILLON PERSONALITY TYPE

INVENTORY ( MPTI ) SEBAGAI INSTRUMEN PENGUKURAN KEPRIB ADIAN DI INDONESIA. Jurnal Psikologi Sains Dan Profesi (Journal Psychology of Science and Profession), 3(2),
65-74.

Viejo, C., Mercedes, G., \& Ortega-ruiz, R. (2018). Adolescents' Psychological Well-Being: A Multidimensional Measure. International Journal of Environmental Research and Public Health, 152325, 1-22. https://doi.org/10.3390/ijerph15102325

Vujcic, M. T., Zganec, A. B., \& Franc, R. (2019). Children and Young Peoples ' Views on Well-Being: A Qualitative Study. Child Indicators Research, 12, 791-819.

Wang, Y. P., Andrade, L. H., \& Gorenstein, C. (2005). Validation of the Beck Depression Inventory for a Portuguese-speaking Chinese community in Brazil. Brazilian Journal of Medical and Biological Research, 38(3), 399-408. https://doi.org/10.1590/S0100879X2005000300011

Yee. (1997). The Social and Cultural Context of Adaptive Aging by Southeast Asian Elders. In J. Sokolavsky (Ed.), The Cultural Context of Aging : Worlwide Perspective (pp. 293303). Westport: CT :Praeger Publisher. 